\title{
POTENSI EKOWISATA PANTAI PINK DALAM RANGKA KONSERVASI ALAM DI KABUPATEN LOMBOK TIMUR
}

\author{
Vita Dini Aviyana ${ }^{1^{*}}$ \\ ${ }^{1}$ Universitas Negeri Jakarta \\ *Email: vitadiniaviyana26@gmail.com
}

\begin{abstract}
Indonesia memiliki potensi daya tarik wisata cukup banyak seperti sumber daya alam, keragaman hayati, dan berbagai nilai budaya yang tersebar di berbagai kawasan nusantara. Realitas ini mencerminkan bahwa Indonesia memiliki prospek untuk dapat dikembangkan sebagai model pengelolaan ekowisata. Pantai Pink Lombok merupakan salah satu dari 11 destinasi wisata pantai di Lombok Timur yang memiliki keindahan alam dan keunikan pasirnya yang berwarna merah muda (Dinas Pariwisata Lombok Timur, 2009). Hutan lindung Sekaroh adalah hutan lindung yang berada di daerah jalan menuju Pantai Pink (bila mengambil alternatif jalur darat melalui Desa Sekaroh). Banyaknya kunjungan dan aktifitas wisatawan domestik dan mancanegara akan membawa dampak negatif terhadap kelestarian lingkungan di sekitar pantai. Adanya alih fungsi lahan untuk pembangunan berbagai fasilitas yang mendukung pariwisata serta pola pemanfaatan sumber daya oleh masyarakat dan pemerintah pun belum sepenuhnya dapat mendukung kelestarian lingkungan serta konservasi hutan lindung di kawasan objek wisata Pantai Pink. Ekowisata menjadi alternatif dalam mengurangi dampak negatif yang terjadi. Ekowisata memberikan peluang untuk mendapatkan keuntungan bagi penyelenggara, pemerintah dan masyarakat setempat, melalui kegiatan-kegiatan yang non-ekstraktif dan non-konsumtif sehingga meningkatkan perekonomian daerah setempat. Penyelenggaraan yang memperhatikan kaidahkaidah ekowisata, mewujudkan ekonomi berkelanjutan. Identifikasi potensi objek wisata Pantai Pink sebagai target ekowisata sangat diperlukan dalam pengembangan pariwisata lingkungan (ekowisata) yang mendukung upaya pelestarian lingkungan (alam dan budaya) dan konservasi, yang melibatkan dan menguntungkan masyarakat setempat, serta menguntungkan secara komersial.
\end{abstract}

Kata kunci: ekowisata; pantai Pink; konservasi 


\section{PENDAHULUAN}

Indonesia merupakan negara kepulauan yang terdiri dari sekian banyak pulau dari Sabang sampai Merauke. Banyaknya pulau yang dimiliki Indonesia, memperlihatkan bahwa Indonesia memiliki pantai yang panjang, sehingga setiap pantai memiliki karakter yang berbeda satu sama lain. Sejarah tumbuhnya kota pantai erat kaitanya dengan masalah perdagangan, transportasi dan ekonomi. Tetapi tidak berarti semua kota yang dekat dengan pantai dapat dikatakan suatu kota pantai yang potensial dan kota yang dapat dengan mudah dikembangkan menjadi kota wisata pantai, karena banyak faktor yang mempengaruhinya, seperti kebutuhan masyarakat, pola hidup, kesadaran masyarakat setempat dan sebagainya.

Pantai merupakan salah satu objek dan daya tarik wisata yang banyak diminati oleh wisatawan, baik itu wisatawan dalam negeri maupun wisatawan mancanegara. Banyak kawasan wisata yang terkenal di dunia terletak di pantai.

“ Pariwista biasanya akan lebih dikembangkan, jika suatu daerah terdapat lebih dari satu jenis objek dan daya tarik wisata". Jenis objek dan daya tarik wisata pantai erat kaitannya dengan aktivitas seperti bejemur matahari, berenang, selancar, berjalan-jalan di tepi pantai, mengumpulkan kerang, berperahu, people watching, berfoto, ski air. Dalam perkembangannya, sektor pariwisata dunia memiliki kecenderungan untuk berubah secara konsep dari Unsustainable forms of tourism menjadi Sustainable Tourism.

Perkembangan industri pariwisata dunia juga menunjukkan pilar barunya yang bernama ekowisata. Menurut Fandeli et al. (2000), ekowisata adalah kegiatan wisata yang memanfaatkan jasa lingkungan, baik itu keindahan dan keunikan alam, ataupun budaya, cara hidup, struktur sosial dalam masyarakat dan unsur-unsur konservasi, edukasi serta pemberdayaan masyarakat setempat.

Potensi wisatawan asing untuk mengunjungi obyek ekowisata selalu meningkat. Seperti dilansir oleh The Internatioanl Ecotourism Society yang menyatakan bahwa pertumbuhan jumlah wisatawan dunia sekitar lima persen setiap tahunnya. Dari jumlah itu sektor ekowisata mengalami pertumbuhan hingga 30 persen. Perkembangan 
ekowisata di tahun-tahun mendatang tampaknya akan semakin pesat, mengingat pada tahun 2002 telah ditetapkan sebagai Tahun Ekowisata Internasional oleh Majelis Umum PBB (The World Ecotourism Summit, 2002).

Aspek ekonomi, ekologi, dan masyarakat sosial diperlukan dalam paradigma pariwisata. Seperti yang dikemukakan oleh Fandeli dan Mukhlison (2000) dalam Gunarto (2004): "Pergeseran paradigma pariwisata dari mass tourism ke individual atau kelompok kecil sangat berperan dalam menjaga keberadaan dan kelestarian obyek dan daya tarik wisata alam, dimana pergeseran paradigma tersebut cukup berarti dalam kepariwisataan alam sehingga perlu diperhatikan aspek ekonomi, ekologi, dan masyarakat lokal (sosial)nya (Fandeli dan Mukhlison 2000 dalam Gunarto 2004)".

Pada sisi lain ekowisata pantai juga merupakan suatu penanaman investasi yang cukup besar dan merupakan salah satu alternatif agar manusia dekat dengan alam dan menjadi salah satu cara yang tepat dalam menjaga lingkungan khususnya dalam upaya konservasi alam.

Seiring dengan meningkatnya kesadaran berbagai pihak terhadap lingkungan dan isu-isu tentang pembangunan yang berwawasan lingkungan telah memberikan konstribusi terhadap pandangan pentingnya prinsip-prinsip wisata berkelanjutan. Prinsip pariwisata yang diharapkan dapat mempertahankan kualitas lingkungan, mempertahankan budaya, memberdayakan masyarakat lokal dan memberikan manfaat ekonomi kepada masyarakat lokal, kawasan dan pemerintah. Ekowisata memberikan nilai tambah kepada pengunjung dan masyarakat setempat dalam bentuk pengetahuan dan pengalaman. Nilai tambah ini mempengaruhi perubahan perilaku dari pengunjung, masyarakat dan pengembang pariwisata agar sadar dan lebih menghargai alam, nilai-nilai peninggalan sejarah dan budaya.

Lombok Timur merupakan salah satu dari sembilan kabupaten/kota Provinsi Nusa Tenggara Barat. Pantai Pink Lombok adalah salah satu destinasi wisata di Lombok Timur yang memiliki keindahan alam dan keunikan pasirnya yang berwarna merah muda. Pantai Tangsi atau yang 
lebih dikenal Pantai Pink ini memiliki panjang sekitar $1,5 \mathrm{~km}$ dengan luas bibir pantai 6 meter di kelilingi perbukitan yang membentuk telukteluk kecil dan di lautnya terdapat beberapa pulau-pulau kecil yang di sebut gili.

Berdasarkan jumlah wisatawan, adanya perbedaan angka pada tahun 2007 dan tahun 2008 memberikan penjelasan bahwa terjadi peningkatan jumlah kunjungan sebesar $2,77 \%$, walaupun peningkatan tersebut masih rendah. Untuk tingkat provinsi Nusa Tenggara Barat pada tahun 2008 pengunjung perhari tercatat 645 orang domestik dan 422 orang pengunjung asing (Departemen Kebudayaan dan Pariwisata RI dan Lombok Timur, 2009). Angka-angka tersebut memberikan harapan terhadap peningkatan di bidang investasi, penyerapan tenaga kerja, peningkatan kontribusi kegiatan pariwisata terhadap pendapatan masyarakat dan pemerintah (Rochajat, 2008).

Bertambahnya jumlah wisatawan sebanding dengan bertambahnya tingkat kerusakan lingkungan yang terjadi di objek wisata tersebut. Kurangnya kesadaran masyarakat terhadap lingkungan, mengakibatkan terjadinya degradasi lingkungan. Berkembangnya pariwisata tidak diikuti dengan kelestarian lingkungan. Oleh karena diperlukan model ekowisata dalam mengembangkan wisata Pantai Pink, pembangunan wisata yang mengedepankan aspek lingkungan, sehingga upaya konservasi alam dan kelestarian lingkungan dapat tercapai.

\section{METODE PENELITIAN}

Teknik pengumpulan data penelitian ini adalah studi kepustakaan, wawancara kepada beberapa responden seperti guide, masyarakat pesisir pantai, pedagang, wisatawan dan pihak lainnya yang terkait dengan Pantai Pink., serta observasi lapangan dilakukan melalui pengamatan dan pencatatan secara sitematik dari berbagai gejala yang diamati tentang lingkungan secara umum dari lingkungan dimana responden berada. Teknik analisis data yang digunakan adalah analisis kualitatif secara deskriptif. Analisis kualitatif berupaya mengkaji fenomena yang satu dengan lainnya dan hubungannya secara dialektis yang kemudian dideskripsikan mengenai fakta-fakta dan sifat-sifat antar hubungan tersebut. Metode ini 
digunakan dalam pengolahan data yang berupa apa saja termasuk kejadian atau gejala yang tidak menggambarkan hitungan, angka, atau kuantitas (Sarwono, 2006).

\section{HASIL DAN PEMBAHASAN}

Hadi (2007) menyatakan bahwa prinsippsinsip ekowisata adalah meminimalkan dampak, menumbuhkan kesadaraan lingkungan dan budaya, memberikan pengalaman positif baik kepada turis (visitors) maupun penerima (host) dan memberikan manfaat dan keberdayaan masyarakat lokal.

Menurut World Conservation Union (WCU), ecotourism adalah perjalanan wisata ke wilayah-wilayah yang lingkungan alamnya masih asli, dengan menghargai warisan budaya dan alamnya, mendukung upaya-upaya konservasi, tidak menghasilkan dampak negatif, dan memberikan keuntungan sosial ekonomi serta menghargai partisipasi penduduk lokal.

Berdasarkan definisi, konsep atau pengertian di atas, maka dapat disusun definisi baru. Ecotourism adalah kegiatan perjalanan wisata yang dikemas secara profesional, terlatih, dan memuat unsur pendidikan, sebagai suatu sektor/usaha ekonomi, yang mempertimbangkan warisan budaya, partisipasi dan kesejahteraan penduduk lokal serta upaya-upaya konservasi sumber daya alam dan lingkungan yaitu tetap menjaga berlangsungnya proses ekologis, melindungi keanekaragaman hayati, kelestarian dan pemanfaatan spesies serta ekosistemnya.

\section{Sejarah dan Potensi Pantai Pink}

Pantai Pink merupakan sebuah pantai yang bernama asli Pantai Tangsi. Tangsi sendiri merupakan sebuah kata yang berasal dari Bahasa Indonesia yang berarti barak atau tempat persembunyian. Konon kabarnya di tempat ini dulunya tempat pernah digunakan sebagai barak tentara Jepang ketika mendarat di Lombok pada tahun 1942. Selain untuk tempat persembunyian, gua ini menjadi tempat untuk mengintai musuh (sekutu) karena letaknya yang strategis dan menghadap pantai. Di sekitar Pantai Tangsi terdapat gua yang dibangun oleh tentara Jepang. Gua-gua tersebut saling berhubungan dan memiliki ujung cabang yang berbeda-beda. Salah satu gua yang terdapat di Pantai Tangsi, berujung di bibir pantai Tanjung Ringgit yang berlokasi sekitar 500 meter dari Pantai 
Tangsi. Selain gua, terdapat pula meriam Jepang yang memiliki panjang 5 meter dengan diameter luar $27 \mathrm{~cm}$ dan diameter dalam $16 \mathrm{~cm}$. Meriam ini berada di kawasan Tanjung Ringgit dan berjumlah 11 buah meriam. Oleh karena kurangnya perhatian pemerintah, saat ini meriam Jepang hanya tersisa satu buah.

Pantai Tangsi ini mulai ramai dibicarakan dalam blogblog traveller sejak tahun 2012. Menurut penuturan dari guide, pantai ini dikenal dengan sebutan Pantai Pink karena adanya istilah yang dibuat oleh mahasiswa UGM melakukan KKN di Dinas Pariwisata dan Kebudayaan Kabupaten Lombok Timur dan berkunjung ke Pantai Tangsi. Mahasiswa tersebut melihat pasir Pantai Tangsi yang tampak berwarna pink dari kejauhan sehingga menyebut Pantai Tangsi dengan nama Pantai Pink. Nama Pantai Pink semakin menyebar dari mulut ke mulut dan menggeser nama asli pantai ini. Kini Pantai Tangsi lebih dikenal dengan sebutan Pantai Pink.

Selama ini kegiatan wisata di Kabupaten Lombok Timur belum begitu berkembang. Geliat wisata di Kabupaten Lombok Timur baru mulai terasa beberapa tahun belakangan ini. Di sekitar kawasan Kecamatan Jerowaru, banyak terdapat villa pribadi dan hotel private yang sengaja tidak dipublikasikan secara luas untuk menjaga suasana alami dan tenang. Di sekitar Pantai Pink ini sendiri, jauh dari dari resort karena letaknya yang jauh dari pemukiman warga dan di kelilingi hutan lindung Sekaroh.

Penyebaran informasi mengenai Pantai Pink yang membuat wisata di Kabupaten Lombok Timur semakin meningkat. Jika wisatawan ingin tinggal di kawasan Pantai Pink, terdapat beberapa penginapan berupa private hotel dan villa yang letaknya jauh dari pantai. Wisatawan juga dapat tinggal di rumah penduduk yang dapat disewa dengan harga relatif murah tutur Santi (34 tahun). Suasana alam dan masyarakat yang masih lugu menjadi daya tarik tersendiri bagi wisatawan yang datang ke Desa Sekaroh yang merupakan lokasi Pantai Pink.

Pantai Pink berada di Kecamatan Jerowaru, Desa Sekaroh, Kabupaten Lombok Timur yang berjarak sekitar 80 $\mathrm{km}$ dari pusat kota Mataram atau sekitar 2,5 jam perjalanan. Pantai Pink bisa 
dicapai melalui 2 jalur, yaitu melalui darat dengan rute Mataram-Praya-Praya Timur-JerowaruTanjung Ringgit yang mana pada $7 \mathrm{~km}$ sebelum Pantai Pink akses jalan cukup rusak. Sementara itu, alternatif lainnya wisatawan bisa memilih rute darat dan laut dengan alur darat Mataram-Praya-Praya TimurSikur-Tanjung Luar. Wisatawan dapat memarkirkan kendaraan di Tanjung Luar yang merupakan kawasan permukiman nelayan. Kemudia wisatawan melanjutkan perjalanan dengan perahu. Harga sewa perahu bisa dinego dengan nelayan, sekitar Rp 350,000 - Rp 500,000 untuk perjalanan bolak balik Tanjung Luar Pantai Pink atau berkeliling seharian. Bila wisatawan memilih jalur darat-laut, wisatawan bisa sekaligus berkeliling di sekitar kawasan Pantai Pink yang terdapat gili (pulau kecil) dan objek menarik lainnya.

Pantai Pink berada di Kabupaten Lombok Timur yang termasuk pada propinsi Nusa Tenggara Barat. Pantai ini memiliki keindahan pemandangan alam laut, perbukitan, pulau kecil dan peninggalan sejarah berupa meriam dan gua Jepang. Pasir pantainya yang berwarna pink mampu memikat hati banyak wisatawan lokal maupun domestik. Berikut ini adalah pemaparan mengenai beberapa potensi ekowisata yang terdapat di Pantai Pink dan sekitarnya yang dapat lebih dikembangkan lagi menjadi daya tarik wisata Pantai Pink:

a. Pasir pantai yang berwarna pink

Pantai Pink memiliki daya tarik tersendiri karena kekhasan warna pasirnya yang berwarna pink. Sebenarnya bukan keseluruhan pasir berwarna pink, tapi merupakan campuran putih dan merah. Warna merah ini berasal dari koral, pecahan kerang, dan kalsium karbonat yang berasal dari hewan laut yang banyak terdapat di perairan dangkal Pantai Pink. Selain itu, warna merah ini juga berasal dari makhluk mikroskopik bernama foraminifera yang memiliki cangkang tubuh kemerahan.

Berdasarkan keterangan masyarakat sekitar, di saat hari cerah, warna pink kurang menonjol sehingga warna pasir lebih tampak putih kekuningan. Pagi pukul 7-8 dan sore hari menjelang matahari terbenam adalah waktu yang tepat untuk melihat warna pink pasir pantai sebab sinar matahari yang terlalu terik pada siang hari kurang 
memunculkan warna pink pada pasir pantai. Warna pink akan lebih terlihat lebih jelas bila cuaca mendung atau hujan dan pasir pantai mengenai terpaan air laut.

b. Gua dan meriam peninggalan Jepang

Di kawasan Pantai Pink, terdapat beberapa gua yang saling berhubungan satu dengan lainnya. Gua-gua tersebut dibangun oleh tentara Jepang pada masa pendudukan Jepang di Indonesia sekitar tahun 1942. Gua-gua tersebut menjadi tempat persembunyian bagi tentara Jepang saat menghadapi serangan pasukan sekutu. Selain gua, terdapat pula meriam yang memiliki panjang 5 meter dengan diameter luar $27 \mathrm{~cm}$ dan diameter dalam $16 \mathrm{~cm}$. Meriam ini berada di kawasan Tanjung Ringgit (500 m dari Pantai Pink) yang merupakan sebuah kawasan tanjung yang menghadap langsung ke Samudera Hindia. Pada awalnya meriam Jepang berjumlah 11 buah meriam, namun saat ini meriam Jepang hanya tersisa 1 buah.

c. Gili Petelu dan Gili Temeak

Gili merupakan sebutan bagi pulau kecil yang berada di sekitar
Pulau Lombok. Di sekitar Pantai Pink sendiri terdapat beberapa gili yang bisa dilihat dari Pantai Pink. Salah satu gili itu adalah Gili Petelu dan Gili Temeak. Gili ini bisa dicapai dengan menggunakan perahu yang bisa disewa oleh pengunjung dari Pantai Pink. Gili Petelu dinamakan demikian karena disana terdapat 3 buah pulau kecil yang berjajar (dalam bahasa asli Lombok, Sasak, telu berarti tiga). Kekayaan flora fauna bawah laut Gili Petelu sangatlah indah. Wisatawan dapat melakukan snorkeling di Gili Petelu.

d. Olahraga pantai (Snorkeling dan Swimming)

Aktivitas snorkeling dapat dilakukan diperairan dangkal sekitar Pantai Pink. Untuk melakukan snorkeling, wisatawan juga dapat melakukannya dengan menyewa perahu dan wisatawan akan diajak berkeliling oleh nelayan ke titik-titik lokasi yang memiliki keindahan alam bawah laut. Di sana terdapat gerombolan karang berwarna hijau terang, bintang laut besar berwarna biru, dan berbagai jenis ikan. Beberapa titik lokasi snorkeling ialah Danau Mangkuk, Gili Gempur, 
dan Gili Petelu. Lokasilokasi tersebut sangat dekat dengan Pantai Pink. Peralatan snorkeling dapat disewa dinelayan-nelayan yang menyewakan perahu. Tarif sewanya sekitar Rp 40.000 - Rp 50.000 sepuasnya.

Daerah Pantai Pink merupakan perairan dangkal dengan arus yang tenang sehingga memungkinkan pengunjung untuk melakukan aktivitas ini. Airnya yang jernih dan bersih akan semakin membuat pengunjung bergairah untuk berenang.

e. Camping

Lokasi ini memungkinkan untuk dilakukannya aktivitas camping, dimana kawasan Pantai Pink berupa tanah datar yang cukup luas. Hal ini sebelumnya telah dilakukan pula oleh anggota Polres Jerowaru.

f. Fishing

Perairan Pantai Pink memiliki kekayaan dalam jumlah dan jenis ikan sehingga memungkinkan untuk kegiatan memancing yang mengasyikan. Banyak pula penduduk setempat yang melakukan aktivitas ini.

g. Pantai Indah atau Pantai Pink 2
Pantai ini dapat dicapai dengan menggunakan perahu sewaan. Pasir pantai ini memiliki kesamaan dengan pasir Pantai Pink yang mana merupakan percampuran antara pasir putih dan serpihan terumbu karang merah. Oleh karena kemiripan pasir pantai, pantai dengan nama asli Pantai Indah ini disebut dengan Pantai Pink 2. Namun keunikan lainnya ialah butiran pasir pantai ini lebih halus dibandingkan dengan pasir Pantai Pink. Pasir pantai ini bertekstur sangat halus seperti tepung sehingga saat menapakkan kaki pada pasir pantai ini, kaki akan masuk pasir hingga mata kaki.

h. Pulau Pasir

Pulau Pasir ialah sebutan untuk sekumpulan pasir yang terdapat di tengah laut yang berada dekat dengan Tanjung Luar (desa nelayan yang menjadi alternatif jalur menuju Pantai Pink). Disaat air laut surut, pasir akan tampak menyembul di tengah lautan. Pulau Pasir dapat dicapai dengan menggunakan perahu yang disewa.

i. Hutan lindung Sekaroh

Hutan lindung Sekaroh merupakan hutan lindung yang 
berada di daerah jalan menuju Pantai Pink (bila mengambil alternatif jalur darat melalui Desa Sekaroh). Hutan lindung Sekaroh memiliki luas 2.834,20 hektar dan menyimpan berbagai keindahan baik fauna maupun satwa yang ada.

j. Perkebunan srikaya, ladang jagung, dan hutan karet

Saat menempuh perjalanan menuju Pantai Pink, para pengunjungi akan disuguhi pemandangan kebun dan ladang. Salah satu kebun yang dibudidayakan oleh masyarakat setempat ialah kebuh buah srikaya, ladang jagung dan lainnya. Di saat musim panen tiba, pengunjung bisa mampir sejenak disalah satu kebun warga dan membeli buah hasil panen secara langsung.

k. Kuliner

Apabila pengunjung datang ke Pantai Pink melalui Tanjung Luar, pengunjung dapat menikmati sajian khas laut yang segara. Tanjung Luar merupakan pasir ikan terbesar yang ada di Pulau Lombok. Disana, pengunjung bisa memilih jenis santapan laut yang mereka inginkan. Penduduk setempat selanjutnya akan mengolah bahan fresh menjadi hidangan yang nikmat. Salah satu makanan yang ada ialah ikan bakar, sambal teri dan menu khas laut lainnya.

\section{Ekowisata Pantai Pink Lombok}

Pantai Pink yang termasuk kawasan Pantai Tanjung Ringgit memiliki keunikan dibandingkan pantai lainnya karena pada umumnya pasir pantai berwarna putih atau hitam sedangkan pasir Pantai Pink merupakan campuran antara pasir putih dan serpihan terumbu karang yang berwarna merah sehingga menjadikan pasir pantai seolah-olah berwarna pink, oleh karena itu masyarakat sekitar menyebutnya Pantai Pink. Berdasarkan keterangan dari Ari (40 tahun), awalnya Pantai Pink lebih dahulu dikenal di kalangan masyarakat melalui informasi dari mulut ke mulut atau pun melalui blog-blog di internet yang membahas mengenai Pantai Pink. Pantai Pink ini belum memiliki media promosi sendiri sehingga hanya sebagian masyarakat saja yang tahu mengenai keberadaan Pantai Pink. Walau mulai dikenal, masih banyak masyarakat yang belum mengetahui obyek wisata Pantai Pink. 
Ketidaktahuan banyak orang terhadap wisata Pantai Pink menunjukan bahwa masih rendahnya tingkat kesadaran dan partisipasi masyarakat dalam pengembangan ekowisata pantai Pink. Hal ini tentu saja menyebabkan potensi ekowisata tersebut tidak berkembang, padahal kesadaran masyarakat akan pengembangan ekowisata tersebut jelas membawa dampak positif bagi masyarakat sekitar lingkungan ekowisata. Pada dasarnya pengetahuan tentang alam, budaya serta kawasan daya tarik wisata juga dimiliki oleh masyarakat setempat. Oleh karena itu kesadaran akan pelibatan masyarakat terhadap pengembangan ekowisata pantai ini menjadi mutlak, mulai dari tingkat perencanaan hingga pada tingkat pengelolaan.

Dalam pengembangan ekowisata itu sendiri terdapat peluang dan tantangan, baik berkaitan dengan masalah ekonomi, sosial, maupun lingkungan. Secara ekonomi, pengembangan ekowisata memberi keuntungan bagi masyarakat lokal di sekitar lokasi tujuan ekowisata, seperti menyediakan kesempatan kerja dan mendorong perkembangan usahausaha baru. Dengan pengelolaan yang terpadu, ekowisata juga berpotensi menggerakkan ekonomi nasional dan mensejahterakan masyarakat di sekitar kawasan ekowisata. Potensi daerah, pengetahuan operator ekowisata tentang pelestarian lingkungan, partisipasi penduduk lokal, kesadaran wisatawan akan kelestarian lingkungan serta regulasi pengelolaan kawasan ekowisata baik di tingkat daerah, nasional dan internasional adalah faktor yang menentukan keberhasilan ekowisata. Satu hal yang tidak boleh diabaikan berkaitan dengan ekowisata adalah pelestarian lingkungan dan penghargaan atas budaya setempat.

Guna mewujudkan kesadaran masyarakat sekitar dalam pengembangan ekowisata pantai, diperlukan adanya suatu upaya yang dilakukan agar kesadaran masyarakat akan pengembangan ekowisata meningkat. Upaya tersebut dimulai dari pelibatan masyarakat setempat. "Pelibatan masyarakat setempat yang memiliki pengetahuan tentang alam dan budaya serta kawasan daya tarik lingkungan sekitar menjadi suatu yang harus dilakukan, mulai dari tingkat perencanaan hingga pada tingkat pengelolaan". Selanjutnya mengarahkan masyarakat sekitar mengenai dampak 
positif yang akan diperoleh dari suatu pengembangan ekowisata pantai ini, yaitu dengan memperlihatkan potensi yang ada pada kawasan ekowisata yang dapat meningkatkan kesadaran dan apresiasi terhadap alam, nilai-nilai peninggalan sejarah dan budaya, serta memberikan nilai tambah kepada pengunjung dan masyarakat setempat dalam bentuk pengetahuan dan pengalaman.

Nilai tambah mempengaruhi perubahan perilaku dari pengunjung, masyarakat dan pengembang ekowisata agar sadar dan lebih menghargai alam, nilai-nilai peninggalan sejarah dan budaya. Selain itu masyarakat setempat juga diberi suatu informasi mengenai manfaat dalam bidang ekonomi dari suatu pengembangan ekowisata, dimana salah satu manfaat tersebut, yaitu ekowisata sebagai sarana mewujudkan ekonomi berkelanjutan, dimana ekonomi berkelanjutan ini merupakan salah upaya dalam memasuki bisnis rekreasi berbasis masyarakat dan ekologi. Seperti yang telah diungkapkan dalam Siaran Pers, Nomor: S.569/PIK-1/2009

"Ekowisata telah berkembang sebagai salah satu industri pariwisata yang potensial untuk meningkatkan penerimaan devisa negara, terutama pada dasawarsa terakhir ini. Hampir 10\% jumlah pekerja di dunia, bekerja di sektor pariwisata dan tidak kurang dari 11\% Gross Domestic Product (GDP) seluruh dunia berasal dari sektor ini. Di Indonesia, ekowisata telah menyumbangkan devisa sebesar Rp. 80 triliun pada tahun 2008 dengan jumlah wisatawan mancanegara" (Siaran Pers 2009).

Penataan Pantai Pink menjadi suatu kawasan ekowisata, dibutuhkan inovasi baik itu infrastruktur bangunan seperti transportasi, hotel juga keamanan dan kenyaman para wisatawan namun tetap mengedepankan kelestarian lingkungan. Miskin inovasi akan terasa sulit untuk memasuki bisnis rekreasi berbasis ekologi dan lingkungan. Bukan hanya bom inovasi, artinya bukan hanya sekali dibuat tapi berlaku untuk seterusnya (berkelanjutan/Sustainable). Faktorfaktor yang perlu dipertimbangkan dalam menggali potensi ekowisata, meliputi lingkungan alam, buatan dan sosial, tahapan, pembiayaan, pengelolaan pembangunan, serta pembinaan dan kelembagaan. Perencanaan penataan dilakukan melalui 
proses dan prosedur penyusunan serta penetapan rencana penataan. Penataan ditinjau kembali dan atau disempurnakan secara berkala mengikuti kriteria dan tata cara yang ditetapkan peraturan pemerintah.

Perlu diketahui juga mengenai sifat dan karakter suatu kawasan untuk menatanya menjadi sebuah kawasan ekowisata. Sifat dan karakter tersebut berupa In-Situ yaitu obyek dan daya tarik wisata alam hanya dapat dinikmati secara utuh dan sempurna di ekosistemnya. Pemindahan obyek ke Ex-situ akan menyebabkan terjadinya perubahan dari obyek dan daya tarik atraksinya. Pada umumnya wisatawan kurang puas apabila tidak mendapatkan sesuatu secara utuh dan apa adanya. Lalu Perishable, yaitu suatu gejala atau proses alam yang hanya terjadi pada kurun waktu tertentu. Kadang siklusnya beberapa tahun, bahkan ada yang puluhan atau ratusan tahun. Obyek dan daya tarik ekowisata yang demikian membutuhkan pengkajian dan pencermatan secara mendalam untuk dipasarkan. Selanjutnya yaitu Non Recoverable, dimana suatu ekosistem alam yang mempunyai sifat dan perilaku pemulihan secara alami sangat tergantung dari faktor alam (Genotype) dan faktor luar (Fenotype). Pada umumnya pemulihan secara alami terjadi dalam waktu yang panjang.

Penataan sebuah kawasan menjadi sebuah wadah ekowisata juga harus memperhatikan aspek-aspek dalam strategi pengembangan objek dan daya tarik wisata alam. Aspek tersebut, meliputi perencanaan pembangunan, kelembagaan, sarana dan prasarana, pengelolaan, pengusahaan, pemasaran, peran serta masyarakat, dan aspek penelitian dan pengembangan. "Aspek perencanaan pembangunan objek dan daya tarik wisata alam, mencakup sistem perencanaan kawasan, penataan ruang (tata ruang wilayah), standarisasi, identifikasi potensi, koordinasi lintas sektoral, pendanaan, dan sistem informasi objek dan daya tarik wisata alam".

Aspek kelembagaan meliputi pemanfaatan dan peningkatan kapasitas institusi sebagai mekanisme yang dapat mengatur berbagai kepentingan, secara operasional merupakan organisasi dengan sumberdaya manusia dan peraturan pemerintah yang sesuai dan memiliki efisiensi tinggi. Aspek sarana dan prasarana yang memiliki dua sisi 
kepentingan, yaitu alat memenuhi kebutuhan pariwisata alam dan sebagai pengendalian dalam rangka memelihara keseimbangan lingkungan, pembangunan sarana dan prasarana. Aspek pengelolaan, yaitu dengan mengembangkan profesionalisme dan pola pengelolaan objek dan daya tarik wisata alam yang siap mendukung kegiatan pariwisata alam dan mampu memanfaatkan potensi obkek dan daya tarik wisata alam secara lestari.

Aspek pengusahaan yang memberi kesempatan dan mengatur pemanfaatan Objek dan daya tarik wisata alam untuk tujuan pariwisata yang bersifat komersial kepada pihak ketiga dan membuka lapangan kerja bagi masyarakat setempat. Aspek pemasaran dengan menggunakan teknologi tinggi dan bekerja sama dengan berbagai pihak baik dalam negeri maupun luar negeri. Aspek peran serta masyarakat melalui kesempatan-kesempatan usaha sehingga ikut membantu meningkatkan kesejahteraan masyarakat. Dan terakhir aspek penelitian dan pengembangan yang meliputi aspek fisik lingkungan, dan sosial ekonomi dari objek dan daya tarik wisata alam.

\section{KESIMPULAN}

Ekowisata dalam era pembangunan berwawasan lingkungan merupakan suatu misi pengembangan wisata alternatif yang tidak menimbulkan banyak dampak negatif, baik terhadap lingkungan maupun terhadap kondisi sosial budaya. 'Ecotourism' mutlak memperhatikan pemeliharaan lingkungan alam (conservation), bukan sebaliknya mengubah keaslian alam sehingga menganggu keseimbangan alam. Pantai Pink Lombok cocok sebagai destinasi wisata yang dapat dijadikan kawasan ekowisata pantai dengan berbagai potensinya. Namun karena rendahnya tingkat kesadaran masyarakat terhadap pengembangan ekowisata pantai, hal tersebut menjadi kendala. Tingkat kesadaran pada masyarakat setempat dapat ditingkatkan dalam pengembangan ekowisata dengan melibatan masyarakat setempat yang memiliki pengetahuan tentang alam dan budaya serta kawasan daya tarik lingkungan sekitar, sehingga dapat membawa dampak positif bagi lingkungan terutama dalam upaya konservasi serta berdampak positif bagi masyarakat setempat seperti terciptannya lapangan kerja. Ekowisata pantai Pink ini juga membantu dalam memasuki 
bisnis rekreasi dengan meningkatnya

devisa negara khususnya pendapatan daerah.

Miskin inovasi akan terasa sulit untuk memasuki bisnis rekreasi berbasis masyarakat dan ekologi atau ekowisata ini. Bukan hanya bom inovasi, artinya bukan hanya sekali dibuat tapi berlaku untuk seterusnya

(berkelanjutan/Sustainable).

Konsekuensi dari ekowisata juga harus diperhitungkan terutama bagi kesejahteraan masyarakat lokal, untuk itu perlu kajian yang mendalam perihal keterlibatan masyarakat dalam pengelolaan ekowisata ini agar masyarakat tidak hanya sebagai objek tetapi juga sebagai subjek yang ikut menjadi pel aku usaha ekowisata yang partisipatif.

\section{DAFTAR PUSTAKA}

Arida, I Nyoman Sukma,2009. Meretas Jalan Ekowisata Bali. Denpasar : Universitas Udayana.

BPS, 2008. Lombok Timur Dalam Angka. Selong : Bintang Timur

Dinas Pariwisata Lombok Timur,2009. Welcome to East Lombok. Buku Panduan Wisata Lombok Timur
Fandeli et al. 2000. Pengusahaan Ekowisata. Yogyakarta: Fakultas Kehutanan Universitas Gadjah Mada.

Gunarto. 2004. Konservasi Mangrove sebagai Pendukung Sumber Hayati Perikanan Pantai. Jurnal Litbang Pertanian, 23(1), 2004.

Gunawan. 1993. Perencanaan Pariwisata: Apa dan Mengapa? Jurnal PWK 7 (Tribulan I): 9-13.

Hadi, S. P. 2007. Pariwisata Berkelanjutan (Sustainable Tourism). Makalah Seminar Sosialisasi Sadar Wisata Edukasi Sadar Wisata bagi Masyarakat di Semarang.

Haeruman, H. 2005. Paradigma Pengelolaan Sumberdaya Alam Indonesia di Masa Mendatang. Bogor: Fakultas Kehutanan Institut Pertanian Bogor.

Komarudin. 1999. Pembangunan Perkotaan Berwawasan Lingkungan. Jakarta: Direktorat Jenderal Cipta Karya Departemen Pekerjaan Umum Bekerjasama dengan Deputi Bidang Pengkajian dan Penerapan Teknologi.

Marpaung, H. 2002. Pengetahuan Kepariwisataan. Bandung: Alfabeta.

Rochajat H, 2009. Prospek Dan Permasalahan Wisata Indonesia. 
http://www.kabarindonesia.com/be rita.php?pil=15\&rubrik $=$ Pariwisata

Sangganagara, H. 2008. Meneguhkan Ekowisata Jawa Barat. Kompas, hal. 33 .
Sarwono, J. (2006). Metode Penelitian Kuantitatif dan Kualitatif. Yogyakarta: Graha Ilmu.

Siaran Pers. 2009. Melambungkan Devisa Melalui Ekowisata. Jakarta: Kementerian Kehutanan Republik Indonesia, Nomor: S.569/PIK$1 / 2009$ 